\title{
PENGOLAHAN TEPUNG BIJI KELUWIH MENJADI KUE KERING
}

\author{
I Putu Oka Januarta, Ni Made Suriani, Damiati \\ Jurusan Pendidikan Kesejahteraan Keluarga \\ Universitas Pendidikan Ganesha \\ Singaraja, Indonesia \\ e-mail: okajanuarta925@yahoo.com,imade.suriani@undiksha.ac.id. \\ damiati@undiksha.ac.id
}

\begin{abstract}
Abstrak
Penelitian eksperimen ini bertujuan untuk mengetahui (1) kualitas kue kering tepung biji keluwih dengan menggunakan subtitusi 50\% tepung terigu dengan 50\% tepung biji keluwih dilihat dari aspek warna,rasa, dan tekstur. Metode pengumpulan data yang menggunakan dalam penelitian ini yaitu metode observasi dengan menggunakan instrumen berupa uji lembar organoleptik dengan 3 tingkat yaitu baik, cukup, dan buruk. Panelis dalam penelitian ini merupakan panelis terlatih yang terdiri dari 15 orang panelis. Teknik analisis data yang digunakan teknik deskriptif kuantitatif. Hasil penelitian ini menunjukan kualitas kue kering tepung biji keluwih dengan menggunakan subtitusi $50 \%$ tepung terigu dengan $50 \%$ tepung biji keluwih dilihat dari aspek (1) warna dengan skor rata-rata 2,66 berada pada kategori baik sesuai dengan tolak ukur warna coklat muda, (2) aspek rasa dengan skor rata-rata 2,53 berada pada kategori baik dengan tolak ukur memiliki rasa manis dan khas tepung biji keluwih, (3) aspek tekstur dengan skor rata-rata 2,86 berada pada kategori baik dengan tolak ukur memiliki tekstur renyah.
\end{abstract}

Kata Kunci : Kue Kering, kualitas, Tepung, Biji Keluwih,

\begin{abstract}
This experimental research is aimed to find out (1) the quality of the cookies with the flour of seeds breadfruit tree using $50 \%$ wheat flour substitution with $50 \%$ flour of seedlings derived from the aspect of color, taste, and texture. Data collection method that use in this research that is observation method by using instrument in the form of organoleptik sheet test with 3 level that is good, enough and bad. The panelists in this study were trained panelists consisting of 15 panelists. Data analysis technique used quantitative descriptive technique. The results of this study showed the quality of the pastry cake flour seeds by using the substitution of $50 \%$ wheat flour with $50 \%$ flour seeds derived from aspect (1) the color with an average score of 2.66 is in good category according to yellow color, (2) the taste aspect with the average score of 2.53 is in the good category with the benchmark has a sweet taste and typical of the flour of seeds, (3) texture aspect with average score 2,86 is in good category with the benchmark has crunchy texture.
\end{abstract}

Keywords: Dried Cake, Quality, flour of seeds, breadfruit tree. 
Jurnal Bosaparis: Pendidikan Kesejahteraan Keluarga

Volume 9, Nomor 2, Juli 2018

\section{PENDAHULUAN}

Bali merupakan salah satu pulau di Indonesia yang memiliki kekayaan alam cukup besar terutama dibidang sumber daya alam, yang memiliki potensi untuk bisa dikembangkan, apalagi Pulau Bali merupakan salah satu pulau yang masih terjaga keasriannya. Oleh karena itu masih banyak sekali yang bisa dikembangkan untuk dijadikan sebagai sumber pendapatan masyarakat sekitar.Salah satu sumber daya alam di Bali yang dapat dikembangkan yaitu ladang pertanian, sektor pertanian di Bali merupakan penyumbang pendapatan daerah terbesar ke dua setelah pariwisata, berdasarkan data Badan Pusat Statistik (BPS) Provinsi Bali (2016). Sumber daya alam di Bali dalam bidang pertanian ada beraneka ragam. Antara lain dapat di manfaatkan sebagai obat-obatan, tanaman hias, dan sebagai bahan makanan yang dapat dikonsumsi sehari-hari. Potensi pertanian di Bali yang menghasilkan tanaman pangan antara lain sayuran dan buah-buahan, adapun hasil produksi dari sayuran yaitu tomat, terong, brokoli dan seldri.Selain itu ada juga hasil produksi dari buah-buahan mangga, pisang, jeruk, rambutan, durian, salak dan keluwih.

Khususnya di Kabupaten Badung selain petani hanya membajak sawah, petani juga menamam pohon pisang, nangka, sukun, dan keluwih, di sela-sela pertanian sehingga parapetani memiliki dua

Biji keluwih memiliki kandungan gizi yang baik, diantaranya kandungan air biji keluwih $67 \%$, kandungan yang dapat dicerna $46 \mathrm{~g}$, kalori $247 \mathrm{kal}$, protein 9,8 gtotal lemak $5.9 \mathrm{~g}$, karbohidrat $52,7 \mathrm{~g}$, serat $2 \mathrm{~g}$, abu 2,2 g, vitamin A $26 \mathrm{Si}$, niacin 4,4 $\mathrm{mg}$, asam pantothenic $0,9 \mathrm{mg}$, vitamin $\mathrm{C} 6,6$ $\mathrm{mg}$, Riboflavin 0,3 mg, Thiamin 0,48 mg, Pada umumnya biji keluwih hanya dimanfaatkan sebagai makanan ringan yang diolah dengan cara merebus biji keluwih. Melihat hal tersebut, biji keluwih belum dimanfaatkan secara optimal oleh masyarakat.Berdasarkan tabeldi atas biji keluwih memiliki kandungan gizi yang sangat baik,dilihat dari segi kandungan biji pengasilan. Di Kebupaten Badung, Kec. Mengwi, di Desa Cemagi banyak masyarakat menamam pohon keluwih di sela-sela sawah. Buah keluwih ini masih sangat minim dimanfaat oleh masyarakat karena kurangnya pengetahuan yang dimiliki oleh masyarakat, karena masyarakat

hanya mengolah sayuran dari buah keluwih, sedangkan biji keluwih kebanyakan di buat sebagai cemilan oleh masyarakat sekitar ( I Gusti Ngurah Wirama ).

Menurut (Atjung 1988) buah keluwih berasal dari nama latinnya Artocarpus Communis Forst = Artocarpus incise.f. Famili moracea. Untuk nama di Indonesia: Keluwih (Indonesia), keluih (Sunda). Buah keluwih merupakan buah yang memiliki kulit yang keras dan memiliki duri kecil-kecil yang hampir mirip dengan buah sukun. Biji buah keluwih ini merupakan limbah dari hasil olahan pembuatan sayuran, yang memisahkan sayuran keluwih dengan bijinya (Sukatiningsih,2005). Biji keluwih memiliki kandungan gizi seperti biji keluwih mengandung kalori, protein, karbohidrat, lemak, kalsium, fosfor, dan zat besi. Selain itu buah keluwih juga menggandung vitamin A, dan vitamin C. Biji keluwih memiliki kadungan sehingga dapat dimanfaatkan sebagai cemilian yang di olah di rebus, diolah menjadi kripik biji keluwih yang enak dan bergizi.

calsium $53 \mathrm{mg}$, tembaga $0,75 \mathrm{mg}$, besi 6,2 $\mathrm{mg}$, Magnesium $100 \mathrm{mg}$, Mangan 0,45 mg, fosfor $268 \mathrm{mg}$, potas $1.620 \mathrm{mg}$, dan sodium $2 \mathrm{mg}$. dari kandungan biji keluwih memiliki banyak kandungan gizi sehingga baik digunakan untuk pembuatan tepung maupun cemilan sehari-hari

keluwih dapat dimanfaatkan menjadi tepung biji keluwih.Dari hasil olahan tepung biji keluwihini belum dimanfaatkan secara optimal, pemanfaatan tepung biji keluwih salah satu olahan tepung biji keluwih adalah brownis.Tepung biji keluwih digunakan sebagai pengganti tepung terigu dalam pembuatan kue brownis, brownis yang 
dibuat dari tepung biji keluwih memiliki tekstur yang lembut dan renyah dan memiliki rasa manis dan terasa khas biji keluwih (Pande 2017:36). Penelitian lain juga permah dilakukan oleh (Agustina 2015:16) dibuat menjadi mie basah yang

Tabel 1. Perbandingan Kandungan Gizi Tepung Biji Keluwih Dan Tepung Terigu Protein Rendah Per 100 Gram

\begin{tabular}{llcc}
\hline No & \multicolumn{1}{c}{ Zat Gizi } & $\begin{array}{c}\text { Tepung Biji } \\
\text { Keluwih }\end{array}$ & $\begin{array}{c}\text { Tepung Terigu } \\
\text { Protein Rendah }\end{array}$ \\
\hline 1 & Karbohidrat & $67,3625 \%$ & $77 \mathrm{gr}(26 \%)$ \\
2 & Kadar air & $6,6348 \%$ & $10 \%$ \\
3 & Lemak (g) & $7,0131 \%$ & $1.5 \mathrm{gr}(2 \%)$ \\
4 & Protein (g) & $15,0640 \%$ & $8 \mathrm{gr}(14 \%)$ \\
5 & Zat besi (mg) & - & $20 \%$ \\
6 & Vitamin B1 & - & $55 \%$ \\
7 & Vitamin B2 & - & $35 \%$ \\
8 & Vitamin B3 & - & $10 \%$ \\
9 & Vitamin D3 & - & $10 \%$ \\
10 & Vitamin A & - & $10 \%$ \\
8 & Pati & $2,3077 \%$ & $20 \%$ \\
9 & Kadar abu & $3,9255 \%$ & $1,60 \%$ \\
10 & Asam folat & - & $240 \%$ \\
11 & Seng & - & $25 \%$ \\
\hline
\end{tabular}

(Sumber 1 :Unit layanan Lab FTP Universitas Udayana 2016)
Berdasarkan tabel di atas tepung biji keluwih memiliki kandungan karbohidrat sebesar 67,3625 \%, kadar air sebesar 6,6348 , lemak sebesar $7,0131 \%$ protein sebesar $15,0640 \%$ pati sebesar 2,3077 \% kadar abu 3,9255 \%. Dari kandungan biji kelwuih sangat baik digunakan untuk pembuatan kue kering.

Tepung biji keluwih merupakan tepung dengan butiran halus yang dihasilkan dari ayakan, yang berwarna keabuan, berbau khas tepung biji keluwih. Proses pembuatan tepung biji keluwih ini menggunakan proses pengeringan. Tepung biji keluwih merupakan produk awetan yang dapat dijadikan bahan alternatif untuk memperpanjang daya simpan, memudahkan penyimpanan dan memperluas jaringan pemasaran serta lebih mudah diolah menjadi produk-produk lain seperti cake, mie basah, dan kue kering

Kue kering adalah kue yang memilikitekstur padat, renyah yang mempunyaikadar air yang sangat rendah karena dibuat dengan cara di oven. Kue memiliki tektstur lembut, warna dari mie basah memiliki warna kuning jingga.Berikut ini merupakan perbandingan kandungan gizi tepung biji keluwih dengan terigu protein rendah adalah sebagai berikut : kering memiliki daya tahan yang cukup lama. Bahan yang digunakan secara umum di dalam pembuatan kue kering diantaranya tepung beras, tepung ketan, terigu maupun sagu, Kue kering yang dioven biasanya di sebut cookies(sumber: https://id.wikipedia.org/wiki/Kue_kering/). Menurut Marsiti (2005:100)Kue kering atau yang sering disebut dengan cookies merupakan adonan yang memiliki ciri-ciri renyah atau melt in the mouth. Adonan pasir merupakan adonan dasar yang digunakan dalam pembuatan berbagai jenis kue kering. Ditinjau dari dari konsistensi adonan pasir dapat dibagi menjadi dua yaitu butter pastry dan foam pastry.

Butter pastry adalah jenis adonan dasar kue kering yang memiliki konsistensi lebih padat atau jenis adonan ini dapat digolongkan sebagai adonan padat. Kue yang termasuk dalam butter pastryadalah biscuit, pie, cookies. Cookies merupakan jenis kue kering yang dibentuk dari adonan pasir.Kue kering merupakan hasil 
pemanggangan dari kombinasi telur, mentega, tepung terigu, susu bubuk, dan gula halus, yang dibentuk dengan cara diiris-iris menggunakan pisau pastry untuk menghasilkan adonan yang memiliki tekstur seperti pasir (Florentina, 2016).

Kue keringtergolong jenis biskuit yang dapat dibedakan seperti crackers, wafeel, dan cookies.Kue Kering atau sering disebut sebagai cookies, berasal dari bahasa Belanda, koekje atau koekie yang berarti little cake (kue kecil).Cookies merupakan kue kering manis yang kecilkecil, yang terbuat dari adonan lunak. Kue keringmemiliki kadar air 1-5\% dan memiliki kadar lemak serta gula yang tinggi, jika di potong memiliki tekstur padat dan renyah. Cookies merupakan salah satu jenis biskuit, kue kering terbuat dari tepung terigu dengan kandungan protein rendah, kue kering juga memiliki serat, kalsium dan vitamin A (Murdopo, 2014).

Pada tahap awal peneliti sudah melakukan praeksperimen yang menggunakan 100\% tepung biji keluwih menjadi kue kering, tetapi kue kering yang dihasilkan tidak memenuhi keteria hasil,

\section{METODE PENELITIAN}

Jenis penelitian yang digunakan dalam penelitian ini adalah penelitian eksperimen. Penelitian ini dilakukan dengan memanfaatkan tepung biji keluwih (Suharsimi Arikunto,2006), metode eksperimen yaitu metode penelitian yang dipergunakan untuk meneliti suatu objek dengan melakukan suatu percobaan secara nyata di lapangan. Produk yang dihasilkan yaitu tepung biji keluwih menjadi kue kering yang akan diuji kualitas dilihat dari aspek warna, rasa, dan tekstur. uji kualitas kue kering tepung biji keluwih mengguanakan uji organeloptik. Dimana panelis diminta untuk mengisi lembaran uji kualitas sesuai tolak ukur yang telah disiapkan. Dari pengisian lembar uji kualitas akan diperoleh data yang kemudian dianalisis sehingga mendapatkan suatu kesimpulan.

Proses dari penelitian tepung biji keluwih menjadi kue kering dimulai dari tahap pengolahan dari kue kering tepung karena kue kering yang dihasilkan dari aspek tekstur tidak memiliki tekstur yang renyah, dan warna yang di hasilkan dari $100 \%$ tepung biji keluwih terlalu coklat.Sehingga melakukan eksperimen yang menggunakan subtitusi $75 \%$ dengan $25 \%$ yang menggunakan tepung biji keluwih dan tepung terigu, dari hasil produk yang dihasilkan menggunakan $75 \%$ dengan $25 \%$ tepung terigu dan tepung biji keluwih tekstur yang dihasilkan kurang renyah. Peneliti melakukan eksperimen tahap ke dua yang menggunakan subtitusi $50 \%$ dengan perbandingan bahan $50 \%$ tepung terigu dan tepung biji keluwih.

Dengan merunjuk pada pemaparan diatas maka penulis akan melakukan penelitian pembuatan kue kering dengan menggunakan bahan utama tepung biji keluwih dengan tepung terigu yang menggunakan subtitusi 50\% : $50 \%$ yang bertujuan untuk memberikan rasa, aroma, tekstur padakue kering tetap renyah, memiliki aroma khas tepung biji keluwih dan rasa manis.

biji keluwih tahapan ini dilakukan sesuai dengan proses persiapan bahan - bahan yang telah ditimbang sesuai dengan resep. Dan sesudah semua bahan disiapkan dilanjukan dengan proses pengolahan kue kering hingga menjadi kue kering tepung biji keluwih yang diharapkan. Tahap berikutnya adalah tahap uji kualitas terhadap kue kering tepung biji keluwih yang telah dibuat kepada panelis yang diambil dari Guru SMK N 1 Seririt, Guru SMK Triatma Jaya Singaraja, Dosesn Pendidikan Kesejahtraan Keluarga dan Mahasiswa Pendidikan Kesejahtraan Keluarga di lingkungan Fakultas Teknik dan Kejuruan Universitas Pendidikan Ganesha.

Tahap terakhir dalam proses penelitian ini adalah analisis data terhadap data yang diproleh sehingga mendapatkan suatu kesimpulan. Dalam penelitian ini peneliti mengguanakn analisis data deskriptif kuantitatif. Produk kue kering ini akan diuji kualitasnya. Dari uji kualitas tersebut akan 
memproleh suatu data yang akan dianalisis dan akan memproleh suatu kesimpulan pada akhir penelitian.

Penelitian ini dilakukan di laboratorium produksi boga jurusan Pendidikan Kesejahteraan Keluarga, Fakultas Teknik dan Kejuruan, Universitas Pendidikan Ganesha, sedangkan untuk waktu pelaksanaan penelitian 2017.

Metode Observasi adalah suatu usaha untuk mengumpulkan data yang dilakukan untuk mengumpulkan data secara sistematis, dengan prosedur yang standar, kemudian observasi bertujuan untuk mengadakan pengukuran terhadap variable yang diteliti (Arikunto,2002:204). Metode observasi digunakan untuk menentukan kualitas terhadap kue kering tepung biji keluwih yang telah dibuat dengan cara memberikan lembar penilaian uji kualitas terhadap kue kering tepung terigu dengan penambahan tepung biji keluwih yang dilihat dari aspek wara, rasa, dan tekstur. Dalam hal ini dapat dinyatakan bahwa metode observasi merupakan cara pengumpulan data dengan melakukan pengamatan secara langsung terhadap suatu objek yang diteliti menggunakan seluruh alat indra (Arikunto,2002:32)

Instrument penelitian dalah alat pengumpul data untuk memproleh data yang diperlukan ketika peneliti sudah menginjak pada langkah pengumpulan data (Sukardi,2010:75). Untuk mencari kualitas dari kue kering tepung biji keluwih dalam penelitian ini peneliti menggunakan uji organoleptik, uji organoleptik yang

Berikut ini adalah rumus yang di gunakan dalam analisis data

$$
\mathbf{M}=\frac{\sum \mathbf{X}}{\mathbf{N}}
$$

digunakan dalam penelitian ini adalah uji mutu hedonik dimana responden diminta tanggapannya tentang baik buruk dari suatu makanan tersebut atau pendapat dari kue kering tepung biji keluwih. Panelis yang digunakan dalam penelitian ini adalah panelis terlatih yang berjumlah 15-25 orang yang diambil dari personal laboratorium tetapi dapat juga karyawan atau pegawai lain (soekarto,1985:48). Dalam penelitian ini panelis yang di gunakan sebanyak 15 orang yang terdiri dari 5 orang Guru SMK N 1 Seririt, 5 orang Guru SMK Triatmajaya Singaraja, 4 orang Dosen Pendidikan Kesejahtraan Keluarga dan 1 orang mahasiswa Pendidikan Kesejahtraan Keluarga Universitas Pendidikan Ganesha.

Di dalam penelitian ini tujuan yang hendak dicapai oleh peneliti yaitu untuk mengetahui tingkat kualitas kue kering tepung biji keluwih yang dilihat dari aspek warna, rasa, dan tekstur. Berdasarkan penelitian tersebut penelitian yang akan digunakan adalah metode analisis deskriptif kuantitatif. Deskriptif kuantitatif adalah suatu cara pengolahan data yang dilakukan dengan jalan menyusun sistematis dalam bentuk angka-angka mengenai suatu objek yang diteliti sehingga akan diproleh kesimpulan umum ( Arikunto 2005 :222). Setelah melalui suatu penelitian tersebut maka akan diproleh kesimpulan pada uji kualitas kue kering tepung biji keluwih yang dilihat dari aspek warna, rasa, dan tekstur. Dari data yang telah didapatkan akan di lanjutkan dengan mencari skor ratarata sehingga memproleh skor rata-rata dari masing-masing aspek.

Keterangan :

M : mean (rata-rata)

$\Sigma x$ : Jumlah masing-masing sekor (rasa, aroma, tekstur) $\mathrm{N} \quad$ : Jumlah subjek (sampel) (sumber: arikunto, 2002) 
Jurnal Bosaparis: Pendidikan Kesejahteraan Keluarga

Volume 9, Nomor 2, Juli 2018

Setelah itu dilakukan tahap interpretasi data dengan skala 3 sebagai beikut:

Table 2. Pedoman Konversi Nilai Skala 3 (tiga)

\begin{tabular}{cc}
\hline Rentangan & Kategori \\
\hline$M+1 S D-M+3 S D$ & Baik \\
$M-1 S D-M+1 S D$ & Cukup \\
M-3SD - M-1SD & Kurang \\
\hline \multicolumn{2}{c}{ ( sumber: Koyan,2011:122) }
\end{tabular}

Keterangan:

$\mathrm{M} \quad=$ Mean atau rata-rata yang dicari

dengan rumus :

$\frac{1}{2} \mathrm{x}($ Skor Minimu +

Skor Maksimum)Type equation here.

$\mathrm{SD} \quad=$ Standar deviasi yang dicari

dengan rumus :

$=\frac{1}{6} x($ Skor Maksimum

- Skor Minimum)Type equation here.

Skor maksimum $=3$

Skor minimum $\quad=1$

Berdasarkan rumus di atas, maka data yang sudah terkumpul akan dicari konversinya. Sehinga mendapatkan hasil sebagai berikut : Minimum )

$$
\mathrm{M}=1 \mathrm{X} \text { ( Skor Maksimum + Skor }
$$

\section{HASIL DAN PEMBAHASAN}

HASIL

Berdasarkan kualitas kue kering tepung biji keluwih yang dibuat oleh peneliti dilaboratorium, memperoleh suatu hasil kue kering yang menggunakan perbandingan $50 \%$ : $50 \%$ tepung biji keluwih dengan tepung terigu, yang dibuat sesuai dengan resep kontrol, dapat memenuhi kriteria hasil yang dilihat dari tiga (3) aspek yaitu : warna, rasa, dan tekstur, warna yang dihasilkan kue kering tepung biji keluwih memiliki warna coklat muda, rasa yang dihasilkan dengan menggunakan perbandingan tepung biji keluwih dengan tepung terigu memiliki rasa manis sesuai dengan resep

$$
\begin{gathered}
M=\frac{1}{2} \times(3+1) \\
M=2 \\
S D=1 \quad \times \frac{(\text { Skor Maksimum }- \text { Skor Minum })}{6} \\
S D=\frac{1}{6} \times(3-1) \\
S D=0,33
\end{gathered}
$$

Acuan pengambilan keputusan yang digunakan untuk menentukan kualitas kue kering tepung biji keluwih dari segi warna, rasa, dan tekstur berdasarkan rumus pedoman konversi dengan skala tiga adalah sebagai berikut :

$$
\begin{array}{ll}
2,33-3 & =\text { Baik } \\
1,67-2,32 & =\text { Cukup } \\
1-1,66=\text { Buruk }
\end{array}
$$

kontrol, sedangakan tekstur tepung biji keluwih memiliki tekstur renyah seseuai dengan perpaduan tiori-tiori dan resep kontrol yang telah digunakan didalam pembuatan tepung biji keluwih.

Warna yang diperoleh dari hasil laboratorium yang diuji kualitas kue kering tepung biji keluwih yang dilihat dari aspek warna memiliki coklat muda yang sudah sesusai dengan tiori kue kering.

Rasa yang dihasilkan dari uji kualitas kue kering tepung biji keluwih memiliki rasa manis, yang dihasilkan dari gula halus, dan susu. Rasa kue kering tepung biji keluwih memiliki rasa manis sesuai dengan kontrol dan kajian tiori. 
Dalam menentukan tekstur dalam suatu produk makanan, ditentukan dengan cara dipotong, diiris, maupun ditekan dengan ujung jari tangan atau meraba pada permukaan makanan. Tekstur yang Hasil Uji Kualitas Kue KeringTepung Biji Keluwih

Dari hasil tabulasi yang diperoleh dari uji panelis terlatih, memperoleh skor rata-rata dari aspek warna 40 , dari aspek rasa memperoleh 38 , sedangkan dari aspek dihasilkan dari uji kualitas kue kering tepung biji keluwih memiliki tekstur renyah yang terbuat dari adonan pasir, yang sudah sesuai dengan tiori-tiori kue kering.

tekstur memperoleh skor rata-rata 43 , dari ke tiga aspek tersbut kue kering memiliki kriteria yang baik, sudah sesuai dengan tolak ukur dan perpaduan teori-teori yang dipergunakan

\section{Tabel 3. Hasil Uji Kualitas Kue KeringTepung Biji Keluwih}

\begin{tabular}{ccccc}
\hline $\begin{array}{c}\text { Aspek Yang } \\
\text { Dinilai }\end{array}$ & $\sum \mathbf{x}$ & $\begin{array}{c}\text { Kue keringtepung biji keluwih } \\
\text { Jumlah } \\
\text { Sampel (N) }\end{array}$ & $\begin{array}{c}\text { Rata-Rata } \\
\text { (Mean) }\end{array}$ & Kategori \\
\hline warna & 40 & 15 & 2,66 & Baik \\
Rasa & 38 & 15 & 2,53 & Baik \\
Tekstur & 43 & 15 & 2,86 & Baik
\end{tabular}

Dari tabel diatas, memperoleh hasil uji panelis terhadap kue keringtepung biji keluwih menyatakan kualitas kue kering tepung biji keluwih yang dilihat dari aspek warna memperoleh skor 2,66, berada pada katagori baik yang sesuai dengan tolak ukur yaitu coklat muda. Kualitas rasa kue kering tepung biji keluwih memperoleh skor 2,53 berada pada katagori baik sesuai dengan tolak ukur yaitu manis dan terasa khas tepung biji keluwih. Kualitas tekstur kue kering tepung biji keluwih memperoleh skor 2,86 yang berada katagori baik sesuai dengan tolak ukur yaitu renyah.

Berdasarkan dari hasil uji kualitas kue kering tepung biji keluwih dilihat dari aspek warna, rasa, dan tekstur, dapat dilihat diagram batang dibawah ini.

\section{Diagram Batang 1. Hasil Uji Kualitas Kue KeringTepung Biji Keluwih}

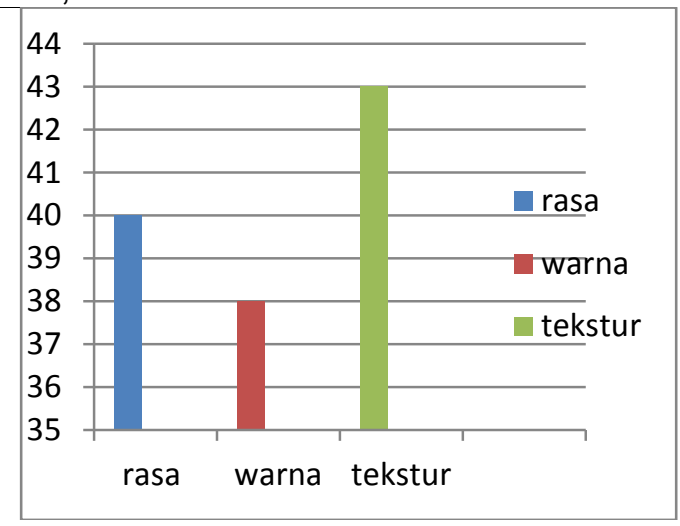

Hasil uji kualitas kue kering biji keluwih berdasarkan rasa memperoleh skor 40 pada kategori baik. Hasil uji kualitas kue kering biji keluwih berdasarkan warna memperoleh skor 38 pada ketegori baik. Hasil uji kualitas kue kering biji keluwih berdasarkan tekstur memperoleh skor 43 pada ketegori baik. Dapat disimpulkan kue kering tepung biji keluwih kategori baik yang diperoleh dari tiga aspek.

\section{PEMBAHASAAN}

\section{Pembahasaan KeringTepung Biji Keluwih Dari Aspek Warna \\ Warna adalah kesan yang diperoleh mata dari warna yang ditimbulkan, untuk menentukan warna dari suatu produk yang}


dapat menarik atau minat dari konsumen untuk mengkonsumsi makanan tersebut.

Hasil uji kualitas kue kering tepung biji keluwih dari aspek warna yang diperoleh dari 15 orang panelis terlatih memperoleh skor rata-rata 2,66. Sebanyak 11 orang panelis menyatakan dari aspek warna kue kering tepung biji keluwih memiliki warna coklat muda, 4 orang panelis terlatih menyatakan kue kering tepung biji keluwih memiliki warna kurang menarik untuk dipasarkan karena warna yang dihasilkan sedikit pucat, dan beberapa panelis menyatakan warna dari kue kering seseuai dengan tolak ukur yang sudah ditentukan. Hal ini menyebabkan kualitas warna kue kering tepung biji keluwih berada pada kategori baik sesuai dengan tolak ukur yang sudah ditentukan.

kue kering tepung biji keluwih yang dibuat sesuai resep baku menghasilkan warna yaitu warna coklat muda. Dalam penelitian ini warna kue kering yang didapat oleh panelis sudah sesuai dengan teori pada kajian pustaka yang meyatakan warna dari kue kering berwarna coklat muda.

\section{Pembahasaan Kualitas Kue KeringTepung Biji Keluwih Dari Aspek Rasa}

Rasa adalah hasil respon terhadap suatu makanan dari penilaian indra pencicip. Rasa dapat dipengaruhi oleh bahan yang digunakan.Kriteria rasa kue kering yang baik dapat dipengaruhi oleh bahan yang digunakan.Cara yang dapat dilakukan untuk menentukan rasa dari kue kering adalah dengan mencicipi kue kering tersebut secara langsung.

Hasil uji kualitas kue kering tepung biji keluwih dari aspek rasa yang diperoleh dari 15 orang panelis terlatih memperoleh skor rata-rata 2,53. Sebanyak 9 orang panelis menyatakan dari aspek rasa kue keringtepung biji keluwih memiliki rasa manis dan khas tepung biji keluwih, 6 orang panelis terlatih menyatakan kue keringtepung biji keluwih memiliki rasa kurang manis, terlalu manis, dan penambahan bahan seperti spekuk atau jahe agar rasa yang ditimbulkan lebih enak. Dari beberapa komentar yang diberikan oleh panelis cookies dari tepung biji keluwih ini sudah sesuai dengan resep baku yang digunakan,hal ini menyebabkan kualitas rasa kue keringtepung biji keluwih berada pada kategori baik sesuai dengan tolak ukur yang ditentukan.

kue keringtepung biji keluwih yang dibuat sesuai resep baku menghasilkan rasa manis. Dalam penelitian ini rasa yang di peroleh sesuai dengan teori yang terdapat pada kajian pustaka yang menyatakan kue keringmemiliki rasa manis. Rasa melibatkan lidah sebagai indra perasa (Soekarto,1985:58). Cara yang baik untuk menentukan rasa dari kue keringadalah dengan mencicipi kue keringtersebut secara langsung. Rasa yang diharapkan pada pembuatan kue keringdari tepung terigu adalah rasa manis.

\section{Pembahasaan Kualitas Kue Kering Tepung Biji Keluwih Dari Aspek Tekstur}

Tekstur adalah jalinan atau penyatuan bagian-bagian sesuatu sehingga membentuk suatu benda. Dalam menentukan tekstur suatu produk makanan, dapat ditentukan dengan cara dipotong, diiris, maupun ditekan dengan ujung jari tangan atau meraba pada permukaan makanan. Tekstur dari suatu hidangan dapat mempengaruhi penampilan hidangan yang disajikan.

Dari hasil uji panelis yang dilakukan, diketahui bahwa kue kering tepung biji keluwih dilihat dari aspek tekstur memperoleh skor rata-rata 2,86 dan sebanyak 14 orang panelis menyatakan tekstur dari kue kering memiliki tekstur renyah serta kering. Dan 1 orang panelis menyatakan tekstur kue keringtepung biji keluwih terlalu renyah. Sehingga kualitas kue keringtepung biji keluwih berada pada kategori baik sesuai dengan tolok ukur yang telah ditentukan yaitu renyah,kue kering tepung biji keluwih memiliki tekstur renyah sesuai dengan resep baku yang sudah dipergunakan. Berdasarkan dari hasil 
penelitian yang didapat hasil dari kue kering tepung biji keluwih sudah sesuai dengan teori yang terdapat pada kajian pustaka yang menyatakan tekstur dari kue kering yang baik adalah bertekstur renyah, yang mempenggaruhi kerenyahan kue kering adalah mentega dan telur.

kue kering tepung biji keluwih yang dibuat sesuai resep baku menghasilkan tekstur yaitu renyah. Dalam penelitian ini tekstur kue kering yang didapat oleh panelis sudah sesuai dengan teori pada kajian pustaka yang meyatakan renyah.

\section{SIMPULAN DAN SARAN SIMPULAN}

Berdasarkan analisis hasil penelitian dan pembahasan, maka kesimpulan yang dapat diambil dalam penelitian ini antara lain hasil uji kualitas kue kering tepung biji keluwih dari aspek warna yang kategori baik yaitu berwarna coklat muda yang memperoleh skor rata-rata 2,66 , sedangkan DAFTAR RUJUKAN

A.A. Gede Agung. 1990. Metedologi Penelitian Pendidikan. Pengantar Ringkas. Singaraja: Sekolah Tinggi Keguruan dan IImu Pendidikan Singaraja.

Agustina Arsiawati Alfa Putri. 2015. Kualitas Mie Basah Dengan Substitusi Tepung Biji Keluwih. Jurnal Fakultas Teknobiologi Universitas Atma Jaya Yogyakarta. Vol. 5

Anonim."Kandungan Biji Keluwih".Tersedia padawww.wikipedia.com, diakses tanggal 21 Februari 2017.

Anonim."Pengertian Kue Kering". Tersedia padawww.wikipedia.com, diakses tanggal 02maret 2017.

Angkasa, S. dan Nazaruddin. 1994. Sukun dan Keluwih. Jakarta: Penebar Swaday.

Atjung.1988. Sayuran Murah Yang Menyehatkan. Jakarta: Bhratara.

Boga Yasa, 2002 Trampil Membuat Kue Kering. Garmedia : Utama.

Bugin, Burhan. 2005. Metodologi Penelitian Kuantitatif Komunikasi, Ekonomi, dari aspek rasa memperoleh skor 2,53 berada dalam kategori baik yaitu memiliki rasa manis khas tepung biji keluwih, sedangkan dari aspek tekstur memperoleh skor rata-rata 2,86, memiliki kategori baik yaitu renyah.

\section{SARAN}

Berdasarkan simpulan penelitian yang telah dikemukakan, maka diajukan beberapa saran. Saran-saran yang dimaksud yaitu sebagai berikut :

1. Dalam pembuatan kue kering sebaiknya menggunakan tepung biji keluwih karena rasa yang ditimbulkan lebih baik.

2. Kepada peneliti selanjutnya dalam pembuatankue keringtepung biji keluwih sebaiknya tidak menggunakan subtitusi tepung terigu, agar hasilnya lebih optimal lagi

Dan Kebijakan Public Setra IImuIImu Social. Jakarta : Kencana

Dessy, Purnama Dewi 2014.Pemanfaatan Tepung Buah Mangrove Jenis Lindur (Bruguiera Gymnorrizha) Menjadi Kue Kering Putri Salju.Jurnal Bosaparis, FTK Universitas Pendidikan Ganesha.

Faizal, Muhammad. Tata Boga Kelas 9 SMP semester 1. Tersedia pada http://muhammadfaizalsajalah.blogs pot.com/2013/12/tata-boga-kelas-9smp-semester-1.html.(diakses pada tanggal 20 Juli 2017)

Florentia Shella Ariantya. 2016. Kualitas Cookies Dengan Kombinasi Tepung Terigu, Pati Batang Aren (Arenga Pinnata) Dan Tepung Jantung Pisang (Musa Paradisiaca).Jurnal Universitas Atma Jaya Yogyakarta Fakultas Teknobiologi Program Studi Biologi Yogyakarta.

Hendrasty, Ir. Hj. Henny Krissetiana.2013. Bahan Produk Bakery. Yogyakarta: Graha IImu.

Hardian Subandoro, 2013.Pemanfaatan Tepung Millet Kuning Dan Tepung 
Jurnal Bosaparis: Pendidikan Kesejahteraan Keluarga

Volume 9, Nomor 2, Juli 2018

Ubi Jalar Kuning Sebagai Subtitusi

Tepung Terigu Dalam Pembuatan Cookies Terhadap Karakteristik Organoleptik Dan Fisikokimia. Jurnal Jurusan analisis pangan Universitas Muhammadiyah Surakarta..

Koyan, I Wayan. 2011. Asesmen Dalam Pendidikan.Singaraja:Universitas Pendidikan Ganesha.

Marsiti, Cok Istri Raka. 2005. Patiseri 1. Singaraja: Teknologi Dan Kejuruan.

Matz, Adam Samuel. 1978. Kimia dan Teknologi Sereal sebagai Makanan dan Pakan. New York: An Avi Book.

Petijo, Setijo. 2005. Keluwih. Jogjakarta: Kanisius.
Sugiyono, 2015.Metologi Penelitian Kuantitatif, Kualitatif, dan R\&D. Bandung:Alfaberta

Sukardi.2010. Metode Penelitian Pendidikan Kompetensi dan Prakteknya. Jakarta: Bumi Aksara

Sukatiningsih.2005. Sifat Fisikokimia dan Fungsional Pati Biji Kluwih (Artocapus Communis G.Forst). Jurnal Jurusan Teknologi Hasil Pertanian Fakultas Teknologi Pertanian Universitas Jember.

Soewarno T Soekarto.1985 Penilaian Organoleptik.Jakarta : Bhratara Karya

Triana, Pande. 2017. "Studi Eksperimen Pengolahan Tepung Biji Keluwih Menjadi Brownis" (Tidak Diterbitkan). Jurusan PKK FTK.UNDIKSHA 